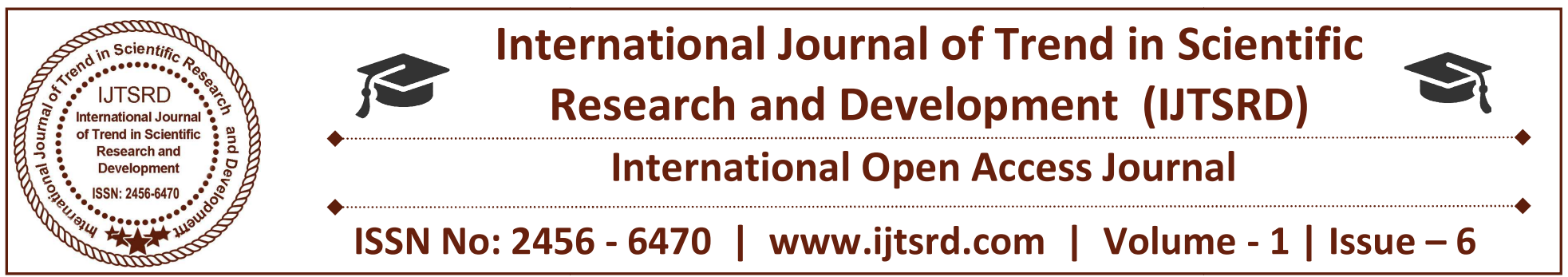

\title{
Political Influence as a Main Livelihood Capital Addressing Climate Change Impacts of Yaaku Community of Laikipia County - Kenya
}

\author{
Kiambi Gilbert M'mboroki \\ Ministry of Agriculture, \\ Livestock Development and \\ Fisheries (State department of \\ livestock)
}

\author{
Shem Wandiga \\ University Nairobi (Institute of \\ climate change and adaptation)
}

\author{
Silas OdongoOriaso \\ University Nairobi (Institute of \\ climate change and adaptation)
}

\begin{abstract}
The objective of the study is to try to indicate that political capital is as important as other capitals if not the controller of other capitals. Data from social ecological survey was analysed after entry in to statistical package for social sciences to get the respondents' views of livelihood capitals. The majority of the respondents $58.5 \%$ in Yaaku community indicated that politicians addressed issues of climate change in the community, with only $18.3 \%$

the politicians were key in addressing the impacts of climate change although they had not known or understood that the impacts are of climate change but either campaign goodies or development agenda. Therefore to address climate change impacts and their adaptations strategies political angle need be applied which makes political influence capital a main livelihood capital in addressing issues of climate change.
\end{abstract} and $30.8 \%$ of them said that climate change issues were addressed by professionals and administrators respectively. However similar respondent of opinion of $45.4 \%, 35.4 \%$ and $17.9 \%$ said it was politicians, professionals and administrators who address development issues respectively. The majority $70.4 \%$ of the respondents gave their opinion that politicians and other leaders do not understand climate related risks on livelihoods while a small minority $29.6 \%$ was on the opinion that the politicians and other leaders understood climate related risks on the livelihoods in pastoral communities. Politicians being the main decision makers on development issues in local set up in developing countries where Kenya is one of them, decisions on climate change and adaption need be discussed and understood by politicians. Therefore policy formulation is needed as from county and national level on how to mainstream politicians in issues of climate change and adaptations. Therefore
Keywords: Political capital, livelihoods, climate change adaptations, impacts, Yaaku

\section{INTRODUCTION}

As indicated by [1] the livelihood capital are "natural (environmental) capital: which is natural resources (land, water, wildlife, biodiversity, environmental resources). Second physical capital: which is basic infrastructure (water, sanitation, energy, transport, and communications), housing and the means and equipment of production. Third human capital: which is health, knowledge, skills, information and ability to labour. Fourth social capital: which are social resources (relationships of trust, membership of groups, networks, access to wider institutions). And lastly financial capital: which is financial resources available (regular remittances or pensions, savings, supplies of credit)".Therefore the essence of policies, 
processes and institutions cannot be overemphasized, because they engage at all levels, from the family to the international arena, and in all spheres, from the most public to the most private[2]. They in a big way determine access (to various types of capital, to decision-making bodies to source of influence and livelihood strategies), returns to any given livelihood strategy and terms of exchange between different types of capitals [2]. Whether people are able to achieve a feeling of inclusion and well-being, there is a direct impact on policies, institutions and processes. Because culture is inclusive in this area they also account for other 'unexplained' variability in the 'way things are done' in different societies [2]. Decision making processes and access to assets can be greatly determined by policies, institutions and processes. The policies, institutions and processes are here referred to as political influence or capital. Figure 1 below shows the mukogodo East ward where Yaaku community resides in mukogodo forest.

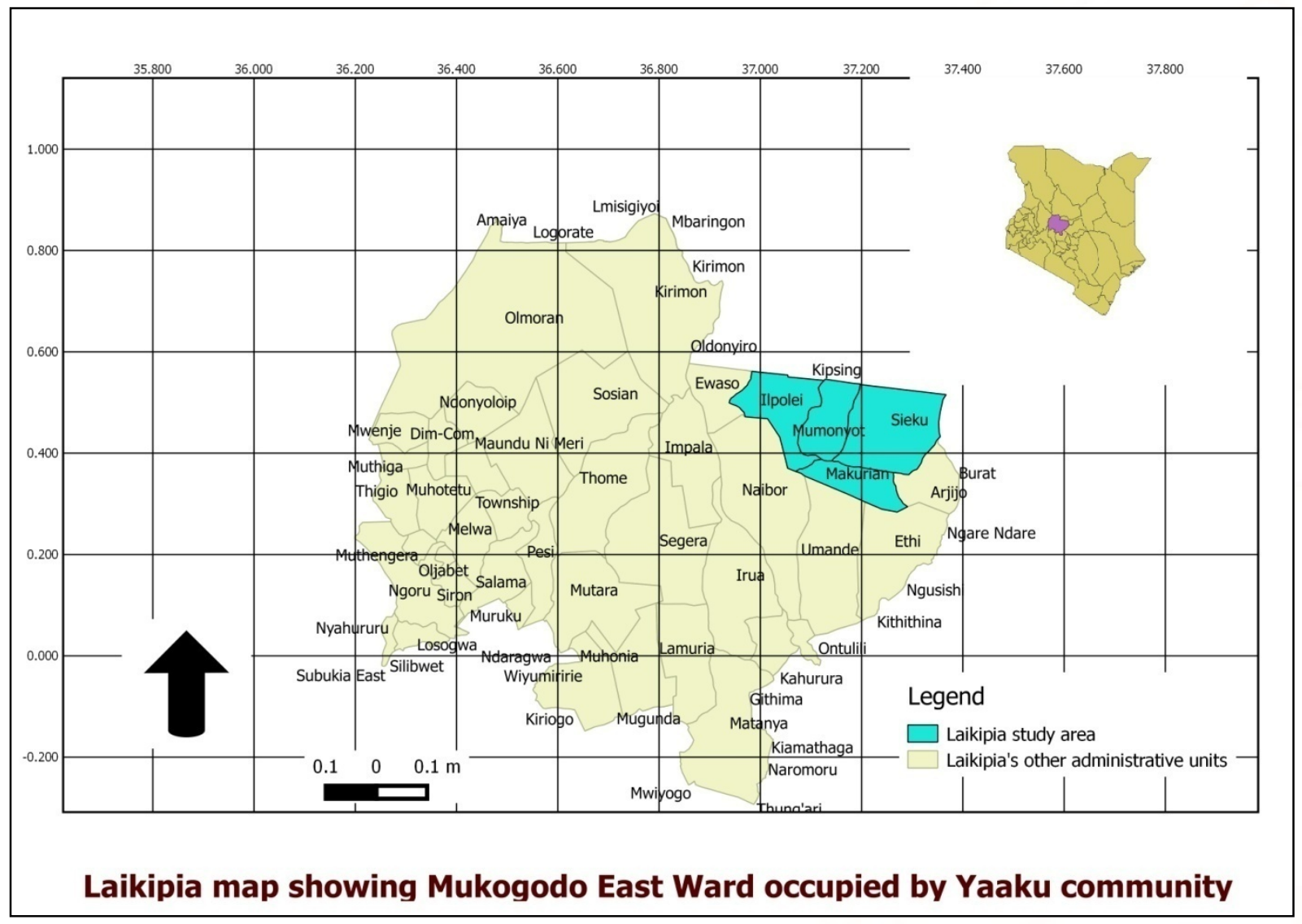

Figure 1: A map of Laikipia County showing the mukogodo East Ward

\section{Methodology}

The study population comprised of 800 households in Mukogodo and Sieku locations in Mukogodo East ward while the sampling frame, from which the study sample was drawn constituted all the households living in the nine villages of these two locations. The unit of analysis was the household and the subject of analysis (the respondent) was the head of the household or their representative.

In each of the nine villages, a list of the households was compiled during the process of community managed disaster and risk reduction (CMDRR) as used by[3], [4], [5], and systematic sampling was used to pick numbers of households (actually about 30 percent of households) from each village[6]. Then

random sampling was undertaken among the systematically selected households in each village, to constitute a study sample of 240 households.

Two formulae from [8], and [7] were used for computing the study sample size, but yielded rather large sample sizes that could not be sustained by the available resources for the study. According to [7], a minimum of 100 is recommended for a survey research and gives a reasonable unit for analysis. 
[6] Indicated that at least $30 \%$ of the total population is representative. Thus, $30 \%$ of the accessible population is enough for the sample size. Thus in this study $30 \%$ of 800 households was (240) respondents.

Hence resorting to the provisions of the Statistical Package for the Social Sciences programme, which suggest that any sample size of 200 and above will allow perfect functioning of all the analytical procedures provided by the programme.

A socio-ecological survey using a structured questionnaire was used to collect respondent's opinion on climate changes and adaptation on land use and management in specific based on livelihood capitals (social capital) for last three decades as from
1986 to 2015. Data from social ecological survey was analysed after entry in to Statistical Package for Social Sciences to get the respondents' views of land use and management within the three decades.

\section{Results and discussions}

Changes in trends in Member of Parliament influence for last three decades

Figure 2 changes in trend in Member of Parliament influence.

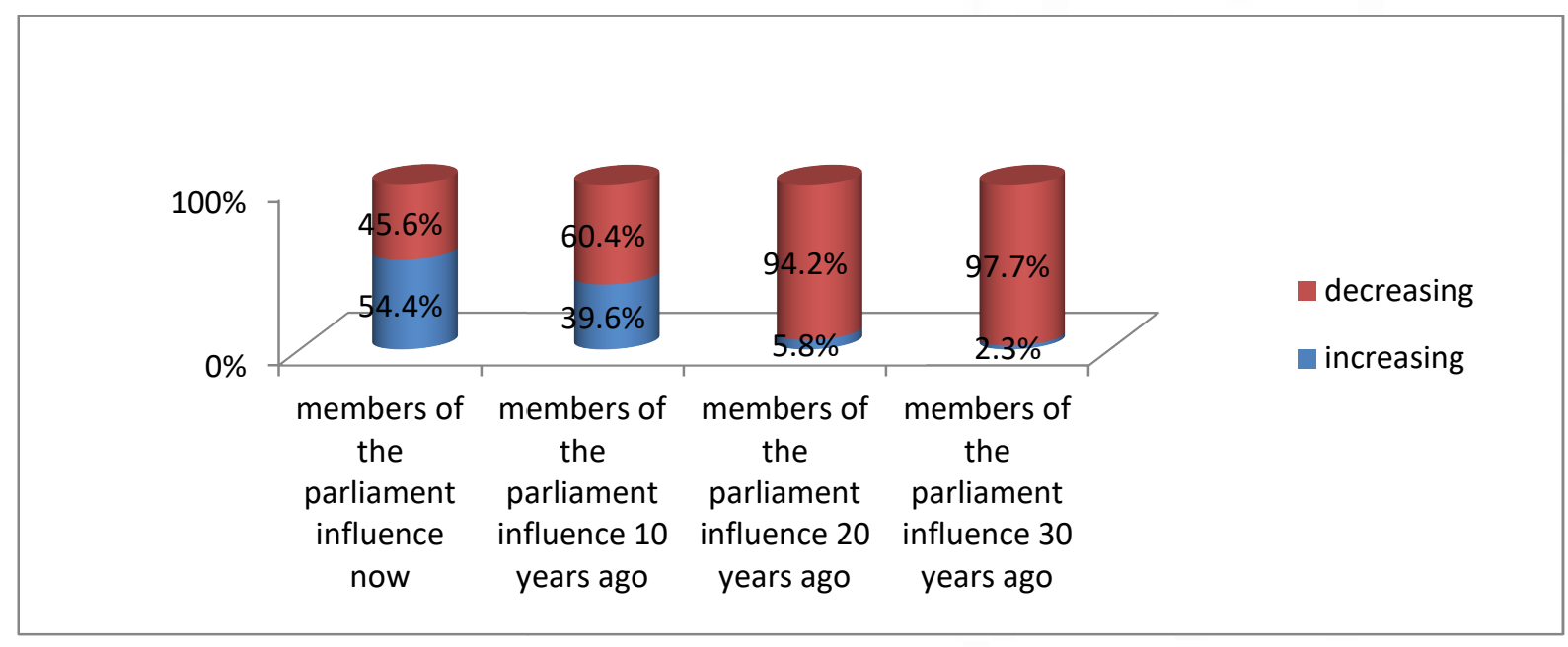

Figure 2: Changes in trends in Member of Parliament influence the last three decades

As indicated by Figure 2, the majority (97.7\%) of the respondents gave their opinion that the trend Member of Parliament was low in last thirty years than now and that the Member of Parliament influence had increased and that average majority $(54.4 \%)$ had the same opinion that the trend in Member of Parliament influence had increased by now as compared to last three decades. In depth discussion at focus group and key informants the issue of low influence in the last thirty and twenty years was associated with marginalisation of the community due low population and also luck of their own in the representation.

Changes in trends in president of the republic influence for the last three decades

Figure 3 below shows changes in president of the republic influence 


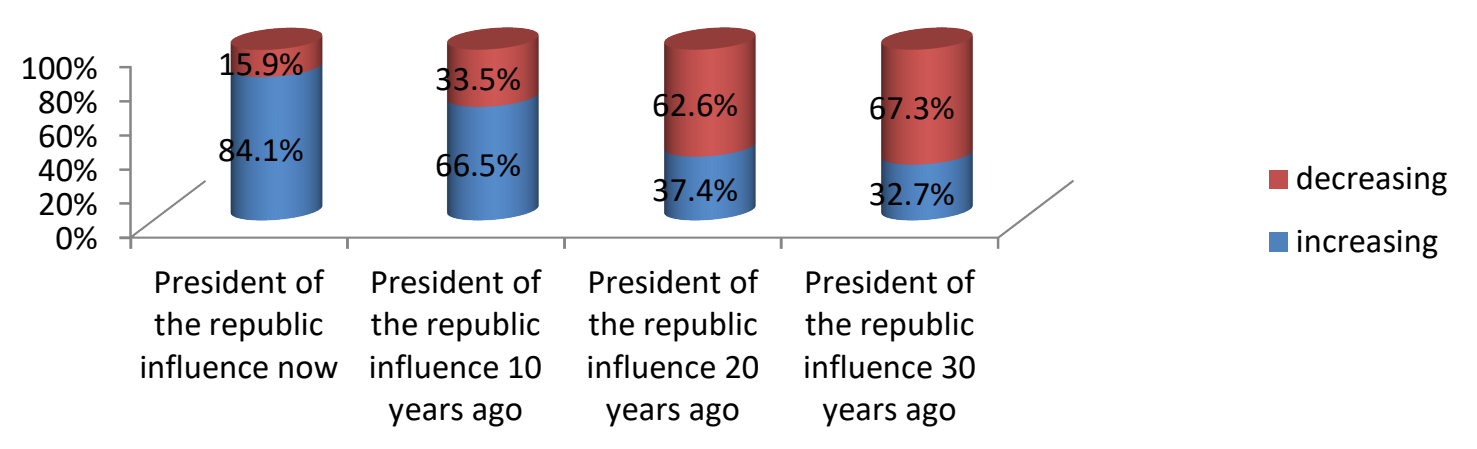

Figure 3: Changes in trends in president of the republic influence the last three decades

As indicated by Figure3, the majority (67.3\%) of the respondents gave their opinion that the trend in the influence of the President of the Republic was low in last thirty years than now and that the trend in the President of the Republic had increased and that the majority $(84.1 \%)$ had the same opinion that the trend in the President of the Republic had increased by now as compared to last three decades. In depth discussion at focus group and key informants the issue of low influence in the last thirty and twenty years was associated with marginalisation of the community due low population which had negligible impact in political sphere, which lead to negligible address of climatic related mitigation measures.

Who address the issues of climate change and adaptation in the community

Figure 4 below shows who addresses the issues of climate change and adaptations in the community

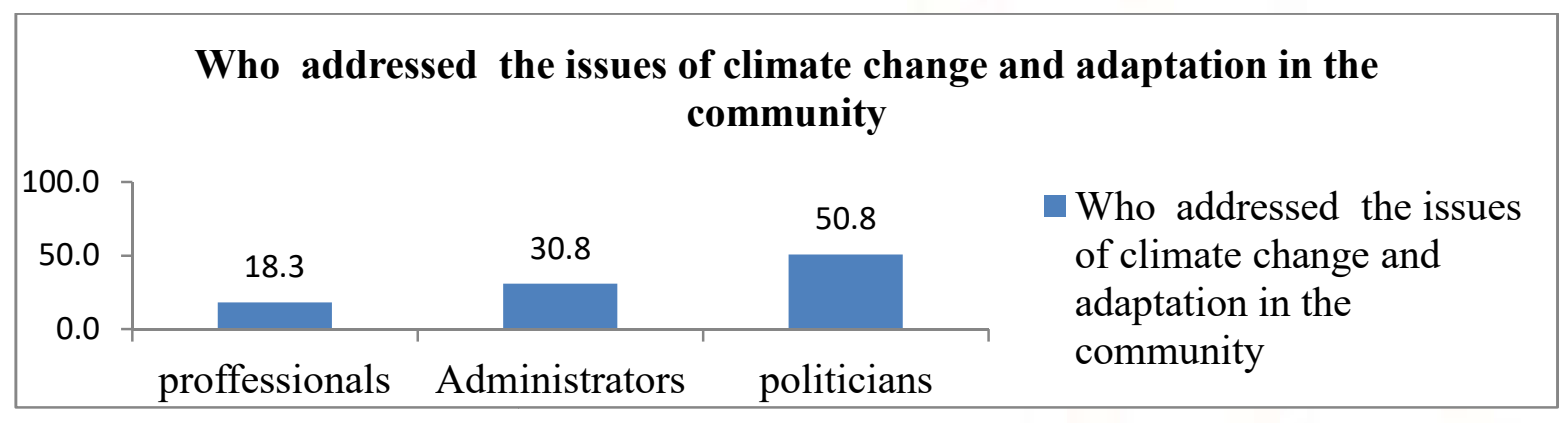

Figure 4: Who addresses the issues of climate change and adaptation in the community

As indicated in Figure 4, the majority of the respondents (58.5\%) in Yaaku community indicated that politicians addressed issues of climate change in the community, with only $18.3 \%$ and $30.8 \%$ of them said that climate change issues were addressed by professionals and administrators respectively. Therefore the politicians were key in addressing the impacts of climate change although they had not known or understood that the impacts are of climate change but either campaign goodies or development agenda (figure 6)

\section{Who address development issues and agenda in the community?}

Figure 5 below shows who addresses development issues in the community 


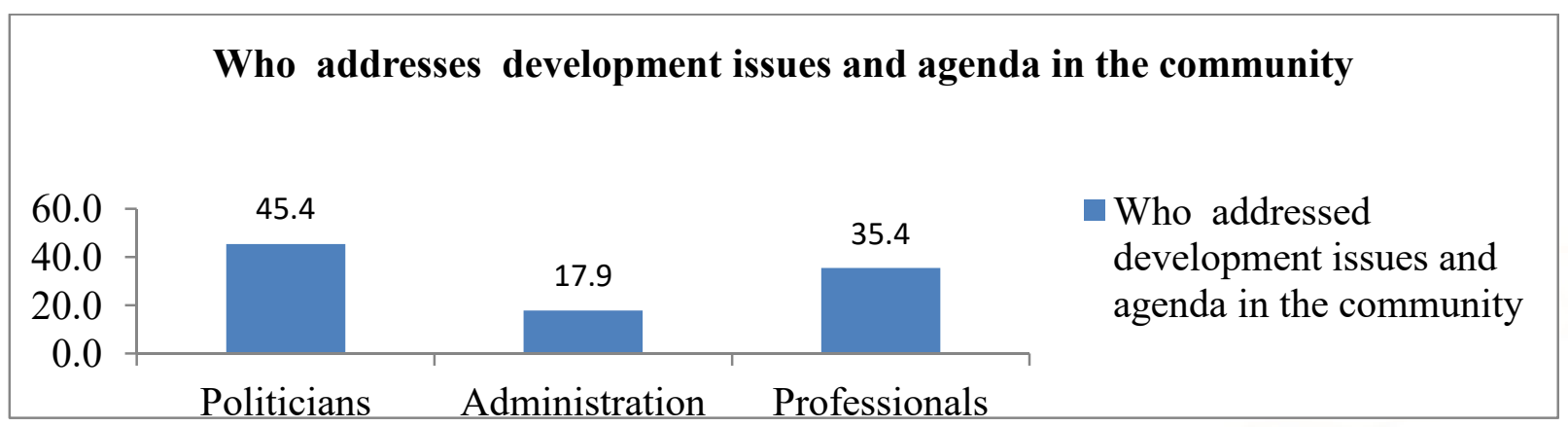

Figure 5: Who addresses the development agenda in the community.

As indicated by Figure 4.56 where almost similar opinion of $45.4 \%, 35.4 \%$ and $17.9 \%$ said it was politicians, professionals and administrators respectively. Therefore the politicians were key in addressing the impacts of climate change although they had not known or understood that the impacts are of climate change but either campaign goodies or development agenda
Do politicians or leaders understand climate related risks on livelihoods?

Figure 6 below shows who understands climate related risks on livelihoods among politicians and other leaders.

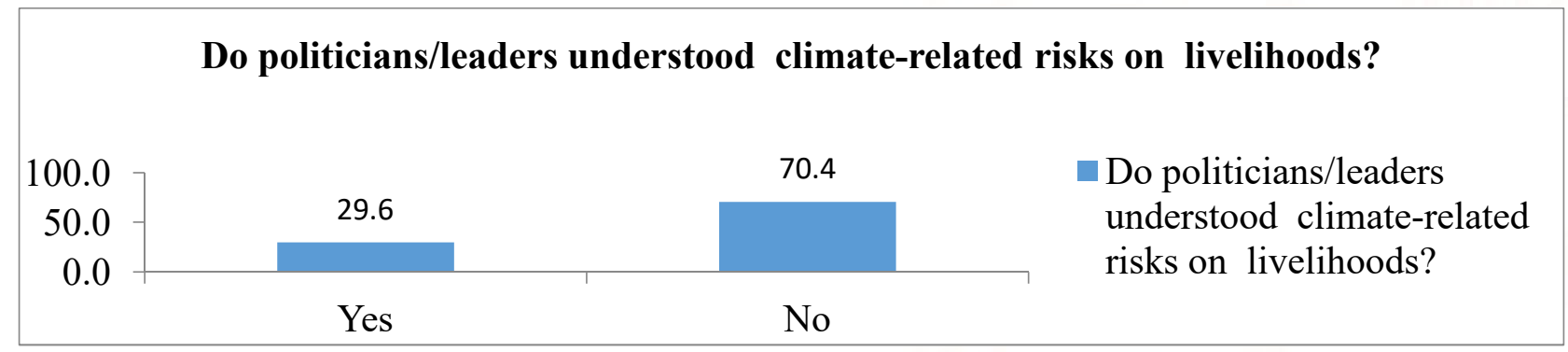

Figure 6: Who understands climate-related risks on livelihoods among politicians and other leaders?

As indicated in Figure 6, the majority (70.4\%) of the respondents gave their opinion that politicians and other leaders do not understand climate related risks on livelihoods while a small minority $(29.6 \%)$ were Figure 7 below shows summary of political capital (increasing) on the opinion that the politicians and other leaders understood climate related risks on the livelihoods in pastoral communities.

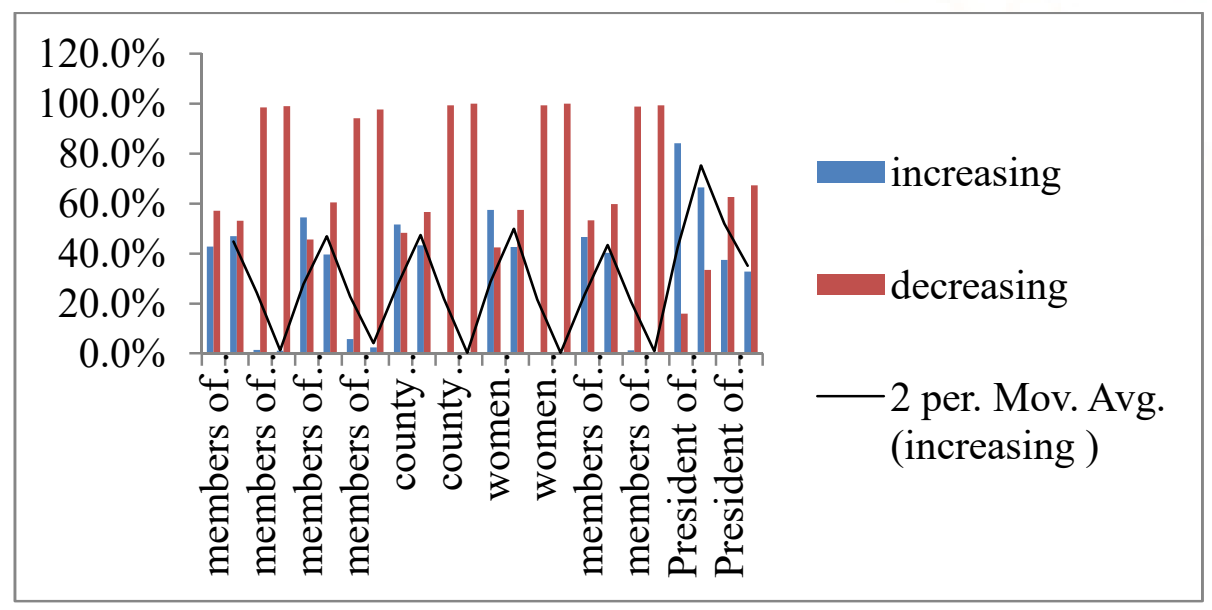

Figure 7: Summary of changes in political capital for the last three decades (increasing) 
As indicated by Figures 7, the opinion on trend of selected political capitals or assets of the respondent of the forested pastoral ecosystem of Mukogodo, home of Yaaku community the trend was increasing in member of county assembly influence, member of parliament influence, county government governor influence, county women representative influence, member of senate influence and President of the republic influence were less in last three decade and increased progressively to present day. This is due to change in governance after the implication of the new constitution few years ago. Figure 8 below shows summary of political capital (decreasing)

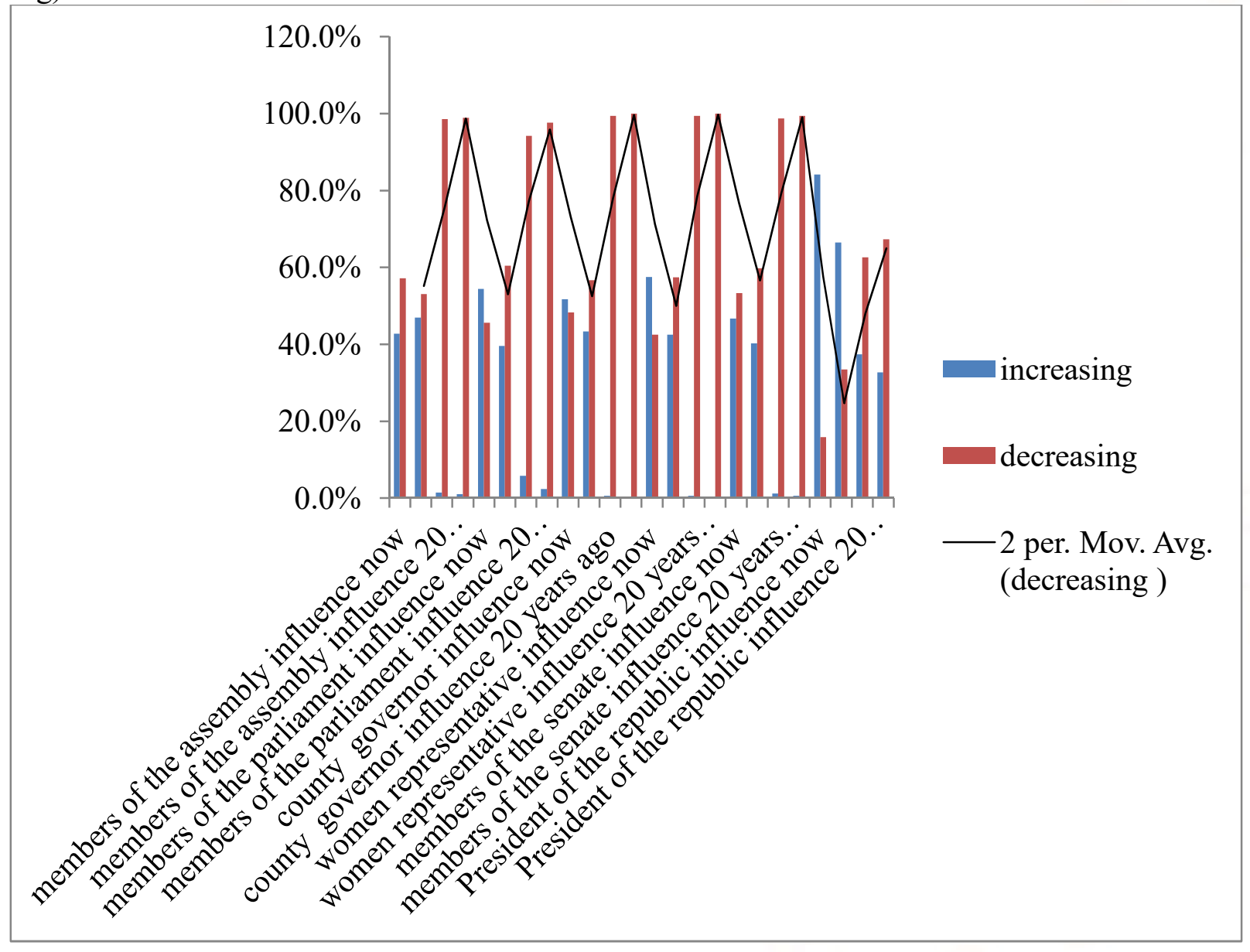

Figure 8: Summary of changes in political capital for the last three decades (decreasing)

As indicated in Figure 8, there was a decreasing influence because some of the political offices like the member of county assembly, county women representative, governor and member of senate were associated with government devolution status coming into being last ten years, thus their offices were not operational in the last thirty and twenty years. However last thirty and twenty years was associated with marginalisation of the community due to low population which had negligible impact in political sphere, which lead to negligible address of climatic related mitigation measures by the political offices of those days.

\section{CONCLUSION}

In this study we adopted the [9] sustainable livelihood frame work with modifications to demonstrate how climatic variability and (context seasonal shocks) on smallholder livelihood assets portfolios are shaped by political influence. Politicians are the main decision makers on development issues in local set up in developing countries where Kenya is one of them. The political influence has increased over the period of thirty years mostly of the Member of Parliament and Presidency. However last thirty and twenty years was associated with marginalisation of the community due to low human population which had negligible impact in political sphere, which lead to negligible address of climatic related mitigation measures by the political offices of day. The political sphere seemed to be the main delivery of adaptations and other issues of climate change. The behaviour of political capital unlike other social capitals such as (networking, conservation groups, and stock friendship) which 
decreased influence as from three decades to date. Political capital increased influence on climate change and adaptation issues. These findings are in conflict with the paradigm shift of top bottom to bottom up. This can be explained by luck of political involvement of the community and generally awareness to issues of climate change and adaptation and also physical distance between the community and the political class. In case of Yaaku community, low human capital in form of education and minority in numbers as led the forested pastoral community to luck political commitment within the community set up.

\section{RECOMMENDATIONS}

Decisions on climate change and adaption need be discussed and understood by politicians and other leaders. Therefore policy formulation is needed as from county level and national level on how to mainstream politicians in issues of climate change and adaptations. Capacity building of the community is recommended on group dynamics and their importance in the community.

That the community is recommended to have organised groups (environmental management committee) as suggested by [10] to address conservation, political and vulnerability issues in the pastoral forested ecosystem

To fast truck increase in political capital for example ( member of county assembly, member of parliament, member of national senate, women representative, County governor and the presidency): Affirmative consideration of non-populous communities in decision making, resources allocation and human resource deployment and involvement of politicians in all issues of climate change and adaptation)

\section{REFERENCES}

[1]Mcleod, R. (2001): The impact of regulations \& procedures on the livelihoods $\&$ asset base of the urban poor; homeless international, www.r4d.afid.gov.uk/pdf/output/R78501.pdf 1005-2016 12.30am.

[2] DFID.(2000): Sustainable Livelihoods Guidance Sheets. Department for International
Development.

http://www.livelihoods.org/info/info guidancesheets.html (accessed: 23.07.2008)

[3] Abdi and cord aid (2011): Technical brief; community managed disaster risk reduction (CMDRR); cord aids strategy for building resilience communities in dry lands areas of east and the horn of Africa. http://www.disasterriskreduction.net/east-central Africa/reglap 20-08-2015, 4.45pm

[4] IIRR and Cord aid. (2013): Building resilient communities. A training manual on community managed disaster risk reduction, Philippines $\mathrm{http}: / / \mathrm{www}$. disasterriskreduction.net/east-centralafrica/reglap 20-08-2015, 4.50pm

[5] CARE International. (2015): Resilience in the rangelands: Changes and challenges for pastoral communities in Kenya and Ethiopia. www.care climate change.org.10-06-2015, 9.47 am

[6] Borg, W. R., \& Gall, M. D. (2003): Educational Research: An Introduction (Fifth Ed.). New York: Longman.

[7] Kathuri, N. J. and Pals, D.A. (1993). Introduction to education research. Egerton University, Njoro Kenya.

[8] Mugenda Olive M. and Mugenda A.G, (1999).Research methods: Quantitative and Qualitativeapproaches. African Centre for technology.

[9] DFID. (1999): Sustainable livelihoods guidance sheets section 2 www.eldis.org/vfile/upload/1/document/0901/sect ion2.pdf. 20-08-2015, 4.00pm

[10] SjoholmHakanand ShabaniLuono(1995): Traditional pastoral communities securing green pastures through participatory forest management: a case study from Kiteto District, United Republic of Tanzania: Second international workshop on participatory forestry in Africa pp 131-151;www.fao.org/3/ay4807b/Y4807B11.pdf $\quad .04-02-2017 \quad 10.12 \mathrm{pm}$ 